\title{
Flame Atomic Absorption Spectrometric Determination of Trace Amounts of Cobalt after Cloud Point Extraction as 2-[(2-Mercaptophenylimino)methyl]phenol Complex
}

\author{
Neda Baghban, Ali Mohammad H. Shabani,* Shayessteh Dadfarnia and Abbas A. Jafari \\ Department of Chemistry, Yazd University, Yazd, 89195-741, Iran
}

\begin{abstract}
Um procedimento de extração no ponto nuvem (CPE) foi desenvolvido para a separação e préconcentração de baixas concentrações de cobalto previamente à determinação por espectrometria de absorção atômica em chama (FAAS). O procedimento é baseado na formação do complexo de Co(II) com 2-[(2-mercaptofenilimino)metil]fenol (MPMP), seguido pela extração em fase rica em surfactante Triton X-114. Alguns parâmetros importantes que afetam a complexação e extração, tais como pH, concentrações do agente quelante e do surfactante, temperatura e tempo de equilíbrio, foram otimizados. Sob condições ótimas, a pré-concentração de um volume de $25 \mathrm{~mL}$ da amostra resultou em um limite de detecção de $0,21 \mu \mathrm{g} \mathrm{L}^{-1}$, um fator de enriquecimento de 97 e um desvio padrão relativo de 1,2\% $\left(n=8,60 \mu \mathrm{g} \mathrm{L}^{-1}\right)$ para a determinação de Co(II) por FI-FAAS. O método foi aplicado com sucesso para amostras de água, vitamina $\mathrm{B}_{12}$ e ampolas de complexo B. A exatidão do método foi comprovada por experimentos de adição-recuperação, análise independente por espectrometria de absorção atômica com forno de grafite e determinação de Co em material de referência certificado.
\end{abstract}

A cloud point extraction (CPE) procedure was developed for the separation and preconcentration of trace amounts of cobalt prior to its determination by flame atomic absorption spectrometry (FAAS). The procedure is based on the formation of $\mathrm{Co}$ (II) complex with 2-[(2-mercaptophenylimino) methyl]phenol (MPMP) followed by its extraction into a Triton X-114 surfactant-rich phase. Some important parameters affecting both complexation and extraction, such as $\mathrm{pH}$, concentrations of chelating agent and surfactant, temperature, and time of equilibration, were optimized. Under optimum conditions, the preconcentration of a volume of $25 \mathrm{~mL}$ of sample resulted in a limit of detection of $0.21 \mu \mathrm{g} \mathrm{L} \mathrm{L}^{-1}$, an enhancement factor of 97 , and a relative standard deviation of $1.2 \%$ $\left(\mathrm{n}=8,60 \mu \mathrm{g} \mathrm{L}^{-1}\right)$ for the determination of $\mathrm{Co}(\mathrm{II})$ by FI-FAAS. This procedure was successfully applied to water, vitamin $\mathrm{B}_{12}$ and $\mathrm{B}$-complex samples. The accuracy was assessed employing addition-recovery experiments, independent analysis by graphite furnace atomic absorption spectrometry and by using a certified reference material.

Keywords: cloud point extraction, cobalt, flame atomic absorption spectroscopy, Triton X-114, 2-[(2-mercaptophenylimino)methyl]phenol

\section{Introduction}

Cobalt is an essential trace element present in most body tissues, with the highest concentrations typically found in the liver. It is a component of vitamin $\mathrm{B}_{12}$ (cyanocobalamin), which is involved in the production of the blood red cells and the prevention of pernicious anemia. ${ }^{1,2}$ Cobalt toxicity is quite low compared to many other metals. However high exposure to this element can cause several health problems such as asthma and skin irritation. ${ }^{3,4}$ Therefore, quantitative determination of cobalt at low concentrations plays an

*e-mail: hshabani@yazduni.ac.ir important role in different fields such as environmental analysis, process control and medicine.

Several analytical techniques including Graphite Furnace Atomic Absorption Spectrometry (GFAAS), ${ }^{5}$ Inductively Coupled Plasma Optical Emission Spectrometry (ICPOES), ${ }^{6}$ Inductively Coupled Plasma Mass Spectrometry (ICP-MS), ${ }^{7}$ and Flame Atomic Absorption Spectrometry $(\text { FAAS })^{8}$ have been used for the determination of cobalt in different matrixes. Despite the development of new, more sensitive analytical methods, the determination of cobalt in natural samples still remains a challenge. In many cases, the analytical instrumentation available does not present the sensitivity requirements necessary to analyze this type of sample. Thus, several procedures have been developed 
for the separation and preconcentration of cobalt, including liquid-liquid extraction, ${ }^{9,10}$ solid phase extraction, ${ }^{11,12}$ coprecipitation, ${ }^{13}$ and flotation. ${ }^{14}$

In recent years, cloud point extraction (CPE) has become one of the most popular methods used in the separation and enrichment of metal ions. ${ }^{15-18}$ The main advantages of cloud point extraction to other techniques of separation are low cost, simplicity, safety, high capacity for preconcentration of wide variety of analytes and high enrichment factor with good recoveries. Non-ionic surfactant solutions become turbid above a certain temperature, called "cloud point temperature". When the cloud point temperature is reached, the micellar solution separates into two phases; a surfactant-rich phase and an essentially bulk aqueous phase. Metal ions can be extracted from the aqueous solution into the small-volume surfactant-rich phase after reacting with a suitable ligand and forming an aqueous low solubility complex. The principles and applications of CPE have been discussed in various interesting reviews. ${ }^{19-21}$

Shift bases derived from salicylaldehyde (salens) are polydentate ligands that play an important role in the development of coordination chemistry as they readily form strong complexes with a wide number of transition metal ions. ${ }^{22,23}$ In analytical chemistry, these ligands have been used as ion carriers in construction of membrane electrodes ${ }^{24,25}$ and as chelating agents in solid phase extraction. ${ }^{26-28}$

This work presents a cloud point extraction procedure for the separation and preconcentration of cobalt (II) ions based on the formation of a hydrophobic complex with 2-[(2-mercaptophenylimino)methyl]phenol (MPMP) (Figure 1). Octylphenoxypolyethoxyethanol (Triton X-114) was used as surfactant and the metallic complex extracted into the surfactant-rich phase was determined by FI-FAAS.

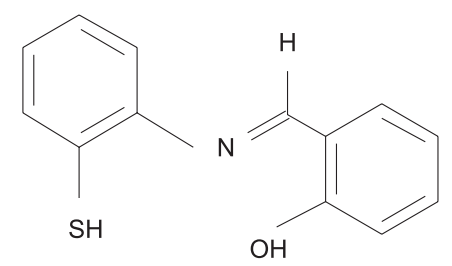

Figure 1. Chemical structure of MPMP.

\section{Experimental}

\section{Apparatus}

A Buck Scientific atomic absorption spectrometer (model 210 VCP, East Norwalk, CT, USA), equipped with a cobalt hollow cathode lamp and an air-acetylene flame atomizer, was used for in all determinations. The wavelength, lamp current and spectral bandwidth used, were $240.7 \mathrm{~nm}, 10 \mathrm{~mA}$ and $0.2 \mathrm{~nm}$, respectively. A single line flow injection system consisted of a peristaltic pump (Ismatic, MS-REGLO/8-100, Zurich, Switzerland) and a rotary injection valve (Rheodyne, Rohnert Park, CA, USA) was used for effective control of the amount of sample and repeatability of the measurements. The $\mathrm{pH}$ measurements were carried out with a Metrohm pH meter (model 691, Herisau, Switzerland) using a combined glass calomel electrode. A centrifuge was used to accelerate the phase separation process (Hittich, Universal 320, Tuttingen, Germany). A thermostated water-bath (Shimi Fann, model S.57, Tehran, Iran) maintained at the desired temperature, was used in the cloud point extraction experiments.

\section{Reagents}

All chemicals used were of analytical reagent grade, unless otherwise stated. Doubly distilled, deionized water was used in all experiments. The stock solution of $1000 \mathrm{mg} \mathrm{L}^{-1}$ cobalt was prepared by dissolving $0.4770 \mathrm{~g}$ of $\mathrm{CoSO}_{4} \cdot 7 \mathrm{H}_{2} \mathrm{O}$ (E. Merck, Darmstadt, Germany) with distilled deionized water into a $100 \mathrm{~mL}$ flask, and diluting it to the mark. Working solutions were prepared from the stock solution by serial dilution with distilled deionized water. The non-ionic surfactant Triton X-114 (Fluka, Chemie AG, Buchs, Switzerland) was used without further purification. The stock solution $(2.5 \% \mathrm{v} / \mathrm{v})$ was prepared by dissolving $2.5 \mathrm{~mL}$ of the concentrated solution in $100 \mathrm{~mL}$ of hot distilled water. A $0.2 \mathrm{~mol} \mathrm{~L}^{-1}$ stock buffer solution was prepared by dissolving an appropriate amount of boric acid (E. Merck) in distilled water and adjusting the $\mathrm{pH}$ to 8.0 by adding diluted $\mathrm{NaOH}$. The ligand, 2-[(2mercaptophenylimino)methyl]phenol was synthesized and purified according to the literature. ${ }^{29,30}$ The MPMP solution $\left(0.02 \mathrm{~mol} \mathrm{~L}^{-1}\right)$ was prepared by dissolving a proper amount of the ligand in ethanol.

The vessels and pipettes used for trace analysis were kept in $10 \%(\mathrm{~m} / \mathrm{v})$ nitric acid for at least $24 \mathrm{~h}$ and subsequently washed four times with doubly distilled water.

\section{Recommended procedure}

An aliquot of the sample or standard solution $(25 \mathrm{~mL})$ containing cobalt(II) in the range of 1-120 $\mu \mathrm{g} \mathrm{L}^{-1}$, Triton $\mathrm{X}-114(0.1 \% \mathrm{v} / \mathrm{v})$, MPMP $\left(1.8 \times 10^{-3} \mathrm{~mol} \mathrm{~L}^{-1}\right)$, and borate buffer with $\mathrm{pH} 8.0\left(8.0 \times 10^{-3} \mathrm{~mol} \mathrm{~L}^{-1}\right)$ were mixed and kept in a thermostated water-bath at $50{ }^{\circ} \mathrm{C}$ for $10 \mathrm{~min}$. The separation into two phases was accelerated by centrifugations at $3500 \mathrm{rpm}$ for $10 \mathrm{~min}$. The mixture was then cooled in an ice bath for $5 \mathrm{~min}$ in order to increase 
the viscosity of the surfactant-rich phase and facilitate the removal of the aqueous phase. A volume of $200 \mu \mathrm{L}$ of a $\mathrm{HNO}_{3} 0.1 \mathrm{~mol} \mathrm{~L}^{-1}$ methanolic solution was added to the remaining surfactant-rich phase to reduce its viscosity before Co determination by FAAS. Finally, in order to effectively control the repeatability of the measurements, an aliquot of $100 \mu \mathrm{L}$ of the resultant solution was introduced into the FAAS system by a single line flow injection (Figure 2).

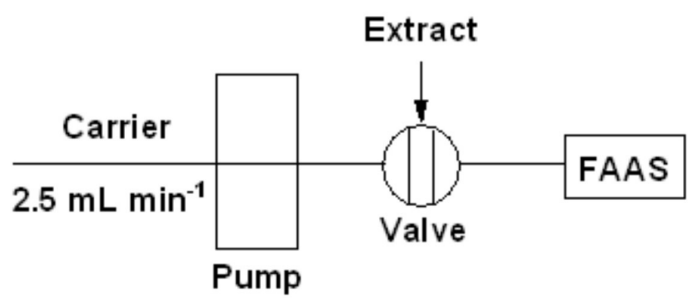

Figure 2. FI-FAAS manifold used for the injection and determination of cobalt.

\section{Sample preparation}

Water samples were filtered with a Millipore $0.45 \mu \mathrm{m}$ pore size membrane (Millipore) into previously cleaned polyethylene bottles. The samples were analyzed within $6 \mathrm{~h}$ of collection according to the recommended procedure.

The content of $2 \mathrm{~mL} \mathrm{~B}$-complex or $1 \mathrm{~mL}$ vitamin $\mathrm{B}_{12}$ ampoules was transferred to a $100 \mathrm{~mL}$ flask and $10 \mathrm{~mL}$ of a mixture of nitric acid and sulfuric acid (10:1 v/v) were added to the sample. The resultant solution was heated to near dryness on a hot plate. The final residue was neutralized with a diluted solution of sodium hydroxide and diluted to $100 \mathrm{~mL}$ with distilled deionized water.

To $0.01 \mathrm{~g}$ of the certified ore, $2 \mathrm{~mL}$ of concentrated nitric acid was added and the sample was heated on a water bath for a few min, then $2 \mathrm{~mL}$ of hydrogen peroxide was added and the mixture was heated for another $5 \mathrm{~min}$. The sample was then filtered through a Millipore filter, the $\mathrm{pH}$ was adjusted to approximately 8 , diluted to the $50 \mathrm{~mL}$, and was treated according to the recommended procedure.

\section{Results and Discussion}

In order to achieve the best performance for the cloud point extraction procedure, the effects of several parameters such as $\mathrm{pH}$, concentrations of ligand and surfactant, temperature, and time of equilibration on the analytical signal were evaluated and optimized.

Separation and preconcentration of metal ions by cloud point extraction involve previous formation of a metallic complex, which needs to present sufficient hydrophobicity to be extracted into the small volume of the surfactantrich phase. The $\mathrm{pH}$ is a critical factor affecting both the reaction between metal ions and ligand molecules, and the metallic complex extractability into the surfactant-rich phase. Thus, the effect of $\mathrm{pH}$ on the cloud point extraction, and ultimately on the cobalt analytical signal, was studied in the range of 2-11. As it can be seen in Figure 3, the maximum Co absorbance was obtained in the $\mathrm{pH}$ range of 7-9. The decrease in absorbance at $\mathrm{pH}>9$ is probably due to the precipitation of cobalt ions as hydroxides, and the signal decrease at $\mathrm{pH}<7$ may be due to competition between hydronium and cobalt ions for complexation with MPMP.

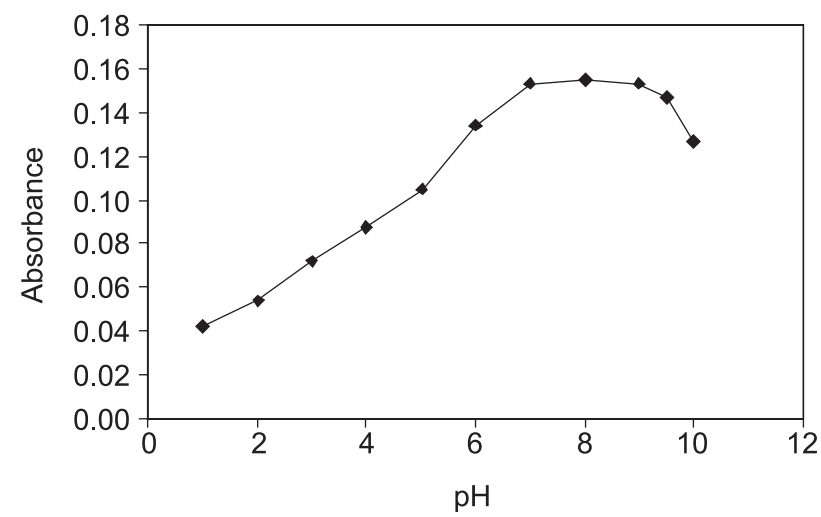

Figure 3. Effect of $\mathrm{pH}$ on the analytical signal of cobalt. Conditions: $60 \mu \mathrm{g} \mathrm{L}-1$ Co, $2 \times 10^{-3} \mathrm{~mol} \mathrm{~L}^{-1}$ MPMP, and $0.15 \%$ (v/v) Triton X-114.

The variation of the analytical signal as a function of the concentration of ligand is shown in Figure 4. As it is seen, the extraction of cobalt increases up to a MPMP concentration of $1.5 \times 10^{-3} \mathrm{~mol} \mathrm{~L}{ }^{-1}$, when it reaches a plateau. At this MPMP concentration the extraction of $60 \mu \mathrm{g} \mathrm{L}^{-1}$ of Co can be considered complete. The MPMP concentration of $1.8 \times 10^{-3} \mathrm{~mol} \mathrm{~L}^{-1}$ was chosen as the optimum condition.

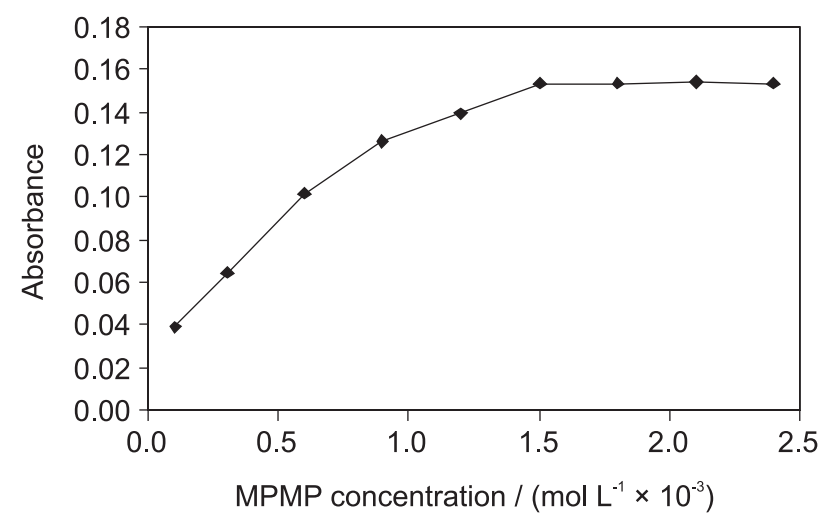

Figure 4. Effect of MPMP concentration on the analytical signal of cobalt. Conditions: $60 \mu \mathrm{g} \mathrm{L}^{-1} \mathrm{Co}, 0.15 \%$ (v/v) Triton X-114, and $\mathrm{pH} 8$. 
Triton X-114 was chosen as non-ionic surfactant in the cloud point extraction procedure due to its commercial availability, low toxicity, high density, and low cloud point temperature. ${ }^{31,32}$ The effect of the Triton X-114 concentration on cobalt extraction was evaluated by varying the surfactant concentration in the range of $0.04-0.2 \%(\mathrm{v} / \mathrm{v})$. As it can be seen in Figure 5, Co absorbance increases as surfactant concentration is increased up to $0.08 \%$ (v/v). Above this Triton $\mathrm{X}-114$ concentration, the analytical signal remains constant. At low concentration of Triton X-114, the extraction efficiency of complex is decreased probably due to the inadequacy of the surfactant assemblies to entrap the hydrophobic complex quantitatively. A Triton X-114 concentration of $0.10 \%(\mathrm{v} / \mathrm{v})$ was employed in all further studies.

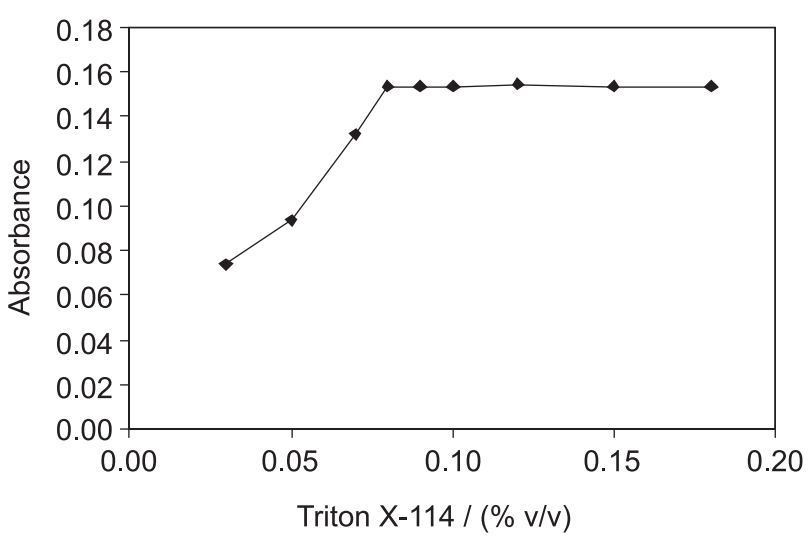

Figure 5. Effect of Triton $X-114$ concentration on the analytical signal of cobalt. Conditions: $60 \mu \mathrm{g} \mathrm{L}{ }^{-1} \mathrm{Co}, \mathrm{MPMP}=1.8 \times 10^{-3} \mathrm{~mol} \mathrm{~L}^{-1}$ and $\mathrm{pH} 8$.

Ionic strength of the aqueous phase can affect the efficiency of extraction by salting out effect. So, the influence of the ionic strength on metal extraction and consequently on the analytical signal was investigated by applying the CPE procedure to cobalt $\left(60 \mu \mathrm{g} \mathrm{L}^{-1}\right)$ standard solutions presenting $\mathrm{NaCl}$ concentrations varying from 0.1-0.6 $\mathrm{mol} \mathrm{L}^{-1}$. It was observed that ionic strength had no significant effect on the cloud point extraction efficiency.

It is desirable a CPE procedure which employs the shortest incubation time and the lowest equilibration temperature possible, considering the compromise between the completion of the reaction and efficiency of the extraction and phase separation. The influence of the equilibration temperature on the cloud point extraction of cobalt was investigated within the range of $25-85^{\circ} \mathrm{C}$. The results showed that the maximum signal intensity for $\mathrm{Co}$ (II) was obtained at temperatures between of 45 and $60{ }^{\circ} \mathrm{C}$. A further increase in temperature resulted in a decrease of the absorbance signal. This may be due to the thermal instability of the Co complex formed with MPMP. So, an equilibration temperature of $50{ }^{\circ} \mathrm{C}$ was used in further experiments. Studies on the effect of the incubation time on the analytical signal were carried out in the range of 5-30 min. Results showed that an incubation time of $10 \mathrm{~min}$ is adequate to obtain quantitative Co extraction and that a further increase in the incubation time would have no significant effect on the extraction efficiency.

The effect of centrifugation time on phase separation was studied in the range of $2-20 \mathrm{~min}$ at $3500 \mathrm{rpm}$. The results showed that a centrifugation of $10 \mathrm{~min}$ is the most adequate to achieve a complete phase separation.

\section{Analytical performance}

A calibration curve was constructed by collecting the analytical signals of different Co standard solutions submitted to the method proposed. Under the optimum experimental conditions, the calibration curve for $\mathrm{Co}$ (II) was linear from 1 to $120 \mu \mathrm{g} \mathrm{L} \mathrm{L}^{-1}$.

The enhancement factor of about 97 was obtained as the ratio between the angular coefficients of the calibration curves for the preconcentrated samples $(25 \mathrm{~mL})$ and the ones not submitted to preconcentration. Limit of detection and limit of quantification defined as $3 \mathrm{~S}_{\mathrm{b}} / \mathrm{m}$, and $10 \mathrm{~S}_{\mathrm{b}} / \mathrm{m}$ (where $S_{b}$ is the standard deviation of the blank and $m$ is the slope of the calibration curve) were $0.21 \mu \mathrm{g} \mathrm{L} \mathrm{L}^{-1}$ and $0.70 \mu \mathrm{g} \mathrm{L}^{-1}$, respectively. The relative standard deviation (RSD) for 8 replicate measurements of $60 \mu \mathrm{g} \mathrm{L}^{-1}$ of cobalt was $1.2 \%$. Table 1 presents the analytical figures of merit for the proposed method.

Table 1. CPE-FI-FAAS figures of merit

\begin{tabular}{lc}
\hline Parameters & Analytical parameter \\
\hline Equation for the calibration curve, & \\
$\mathrm{C} /\left(\mu \mathrm{g} \mathrm{L}^{-1}\right)$ & $\mathrm{A}=2.3 \times 10^{-3} \mathrm{C}_{\mathrm{Co}}+0.012$ \\
Correlation coefficient & 0.9994 \\
Linear range / $\left(\mu \mathrm{g} \mathrm{L}^{-1}\right)$ & $1-120$ \\
Enhancement factor & 97 \\
Limit of detection / $\left(\mu \mathrm{g} \mathrm{L}^{-1}\right)$ & 0.21 \\
$\mathrm{RSD}, \%(\mathrm{n}=8)$ & 1.2 \\
\hline
\end{tabular}

\section{Interferences}

The effect of different cations and anions on the determination of $50 \mu \mathrm{g} \mathrm{L}^{-1}$ of cobalt (II) ions at mol ratio of 1000 by the proposed method was evaluated. An ion was considered to be an interferent when it caused an error greater than $\pm 5 \%$ in the determination of cobalt. When the error was greater than $\pm 5 \%$, the amount of interferent ion was lowered. The results are given in Table 2. At the given mole ratio no interference was observed and the recovery of cobalt was quantitative in the presence of all foreign ions studied. Those results indicate the efficiency of the method proposed and its potential for real sample applications. 


\section{Application}

The feasibility of the method proposed for cobalt determination in different matrixes was investigated. The method was applied to water samples and vitamin ampoules. The accuracy was checked by spiking the

Table 2. Effect of foreign ions

\begin{tabular}{lcc}
\hline Ions & Mole ratio (ion/ $\left.\mathrm{Co}^{2+}\right)$ & Recovery / $(\%)$ \\
\hline $\mathrm{NO}_{3}{ }^{-}$ & 1000 & 100 \\
$\mathrm{SO}_{4}^{2-}$ & 1000 & 95.3 \\
$\mathrm{Cd}^{2+}$ & 1000 & 98.5 \\
$\mathrm{Mg}^{2+}$ & 1000 & 96.6 \\
$\mathrm{Mn}^{2+}$ & 1000 & 95.3 \\
$\mathrm{Al}^{3+}$ & 1000 & 95.4 \\
$\mathrm{Ag}^{+}$ & 1000 & 97.3 \\
$\mathrm{~Pb}^{2+}$ & 1000 & 99.9 \\
$\mathrm{~K}^{+}$ & 1000 & 98.4 \\
$\mathrm{Hg}^{+}$ & 1000 & 96.6 \\
$\mathrm{Na}^{+}$ & 1000 & 101 \\
$\mathrm{Cl}^{-}$ & 1000 & 99.7 \\
$\mathrm{Br}^{-}$ & 1000 & 99.1 \\
$\mathrm{Ca}^{2+}$ & 500 & 96.5 \\
$\mathrm{Sr}^{2+}$ & 500 & 98.4 \\
$\mathrm{Fe}^{2+}$ & 500 & 97.2 \\
$\mathrm{PO}_{4}^{3-}$ & 250 & 98.6 \\
$\mathrm{Zn}^{2+}$ & 250 & 99.7 \\
$\mathrm{Cu}^{2+}$ & 100 & 96.5 \\
$\mathrm{Ag}^{+}$ & 100 & 95.3 \\
$\mathrm{Cr}^{3+}$ & 50 & 98.3 \\
$\mathrm{Ni}^{2+}$ & 50 & 99.0 \\
$\mathrm{Fe}^{3+}$ & 50 & 99.2 \\
\hline & &
\end{tabular}

samples with different concentrations of Co and comparing the values obtained with the method proposed with data from direct analysis by graphite furnace atomic absorption spectrometry (GFAAS). The results given in Tables 3 and 4 show recoveries greater than $97 \%$ and satisfactory agreement between the values determined by both methods, at a $95 \%$ confidence limit. Those results suggest that the proposed method is suitable for the sample types examined. To additionally validate the accuracy of the method, cobalt was determined in a certified nickel-copper-cobalt reference ore SU-1a (Canadian Certified Reference Materials Project). The concentration of cobalt determined by the method proposed presented no significant difference from the value certified in a 95\% level of confidence (Table 3). Thus, the method proposed can be considered reliable for Co determination in a wide range of samples.

\section{Conclusions}

A simple, fast, inexpensive and sensitive cloud point extraction method has been developed for the determination of trace amounts of cobalt in aqueous samples by FI-FAAS. A sensitivity improvement has been achieved by the method proposed when compared to previously reported works using CPE and FAAS (Table 5). The method proposed can be applied to the determination of cobalt in different water samples, vitamin $\mathrm{B}_{12}$, and B-complex ampoules.

Table 3. Determination of cobalt in water samples and a certified nickel-copper-cobalt reference ore (SU-1a)

\begin{tabular}{|c|c|c|c|c|}
\hline Samples & Added / $\left(\mu \mathrm{g} \mathrm{L}^{-1}\right)$ & Found $^{\mathrm{a}} /\left(\mu \mathrm{g} \mathrm{L}^{-1}\right)$ & Recovery / (\%) & $\mathrm{ETAAS}^{\mathrm{a}} /\left(\mu \mathrm{g} \mathrm{L}^{-1}\right)$ \\
\hline \multirow{3}{*}{ Well water } & 0.0 & $1.62 \pm 0.04$ & & $1.72 \pm 0.11$ \\
\hline & 10.0 & $11.4 \pm 0.2$ & 97.8 & \\
\hline & 20.0 & $21.5 \pm 0.2$ & 99.4 & \\
\hline \multirow{3}{*}{ River water } & 0.0 & $4.61 \pm 0.13$ & & $4.71 \pm 0.23$ \\
\hline & 10.0 & $14.5 \pm 0.3$ & 98.9 & \\
\hline & 20.0 & $24.4 \pm 0.4$ & 99.0 & \\
\hline \multirow{3}{*}{ Tap water } & 0.0 & n.d. ${ }^{\mathrm{b}}$ & & n.d. \\
\hline & 10.0 & $9.72 \pm 0.21$ & 97.2 & \\
\hline & 20.0 & $19.8 \pm 0.4$ & 99.0 & \\
\hline SU-1 $\mathrm{a}^{\mathrm{c}}$ & & $0.040 \pm 0.001(\%)$ & 97.6 & \\
\hline
\end{tabular}

${ }^{\mathrm{a}} \mathrm{Mean}$ and standard deviation related to three determinations. ${ }^{\mathrm{b}}$ Not detected. ${ }^{\mathrm{c}} \mathrm{Composition}: \mathrm{Ni}=1.233 \pm 0.008 \%, \mathrm{Cu}=0.967 \pm 0.005 \%, \mathrm{Co}=0.041 \pm$ $0.001 \%, \mathrm{Ag}=4.3 \pm 0.3 \mu \mathrm{g} \mathrm{g}^{-1}, \mathrm{Pt}=0.41 \pm 0.06 \mu \mathrm{g} \mathrm{g}^{-1}$, and $\mathrm{Pd}=0.37 \pm 0.03 \mu \mathrm{g} \mathrm{g}^{-1}$.

Table 4. Determination of cobalt in vitamin ampoules

\begin{tabular}{lcccc}
\hline Samples & Added $/ \mu \mathrm{g}$ & Found $/ \mu \mathrm{g}$ & Recovery $/ \%$ & GFAAS $^{\mathrm{c}} / \mu \mathrm{g}$ \\
\hline B Complex $^{\mathrm{a}}$ & 0.0 & $0.35 \pm 0.01$ & & $0.34 \pm 0.02$ \\
$\mathrm{~B}_{12}{ }^{\mathrm{b}}$ & 2 & $2.30 \pm 0.04$ & 97.5 & $4.48 \pm 0.07$ \\
\hline
\end{tabular}

aLorestan Co. Iran: Each ampoule $(2 \mathrm{~mL})$ contains: vitamin $\mathrm{B}_{12}(8 \mu \mathrm{g})$ equivalent to $0.35 \mu \mathrm{g} \mathrm{Co}$, vitamin $\mathrm{B}_{2}(4 \mathrm{mg})$, vitamin $\mathrm{B}_{6}(4 \mathrm{mg})$, vitamin $\mathrm{B}_{1}(10 \mathrm{mg})$,

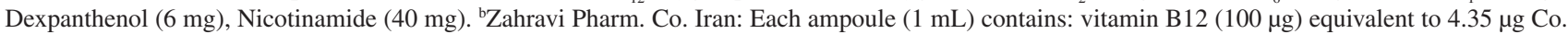
${ }^{\mathrm{c}}$ Mean and standard deviation of three determinations. 
Table 5. Procedure using cloud point extraction prior cobalt determination by FAAS

\begin{tabular}{|c|c|c|c|c|c|}
\hline Reagent & Surfactant & $\begin{array}{c}\text { Sample } \\
\text { volume / } \mathrm{mL}\end{array}$ & $\mathrm{EF}^{\mathrm{a}}$ & $\begin{array}{l}\mathrm{LOD}^{\mathrm{b}} / \\
\left(\mu \mathrm{g} \mathrm{L}{ }^{-1}\right)\end{array}$ & Reference \\
\hline ammonium pyrrolidinedithiocarbamate & Triton X-114 & 10 & 20 & 5 & 33 \\
\hline 1-(2-thiazolylazo)-2-naphthol & Triton X-114 & 50 & 57 & 0.24 & 34 \\
\hline 1-(2-pyridylazo)-2-naphthol & Triton X-114 & 10 & 115 & 0.38 & 35 \\
\hline \multirow[t]{2}{*}{ 2-(5-bromo-2-pyridylazo)-5-diethylaminophenol } & Triton X-100, SDS & 12.5 & $28.5^{\mathrm{c}}$ & $1.06^{\mathrm{c}}$ & 36 \\
\hline & & & $21.7^{\mathrm{d}}$ & $1.58^{\mathrm{d}}$ & \\
\hline 1-nitroso-2-naphthol & PONPE 7.5 & 10 & 27 & 1.22 & 37 \\
\hline 2-[2'-(6-methyl-benzothiazolylazo)]-4-bromophenol & Triton X-114 & 10 & 28 & 0.9 & 38 \\
\hline Methyl-2-pyridylketone oxime & Triton X-114 & 15 & 67 & 2.1 & 39 \\
\hline 2-[(2-mercaptophenylimino)methl]phenol & Triton X-114 & 25 & 97 & 0.21 & This work \\
\hline
\end{tabular}

${ }^{\mathrm{a}}$ Enhancement factor, ${ }^{\mathrm{b}}$ limit of detection, ${ }^{\mathrm{c}}$ in presence of hydrochloric acid, ${ }^{\mathrm{d}}$ in presence of sodium chloride.

\section{Acknowledgment}

The authors wish to thank the graduate school of Yazd University for their support.

\section{References}

1. Underwood, E. J.; Trace Elements in Human and Nutritions, $4^{\text {th }}$ ed., Academic Press: New York, 1977.

2. Seiler, H. G.; Siegel, A.; Siegel, H.; Handbook on Metals in Clinical Analytical Chemistry, Marcel Dekker: New York, 1994.

3. McKenzie, H. A.; Smythe, L. E.; Quantitative Trace Analysis of Biological Materials, Elsevier: New York, 1988.

4. Belitz; H. D.; Grosch, W.; Food Chemistry, Springer-Verlag: Berlin, 1987.

5. Ribeiro, A. S.; Vieira, M. A.; Silva, A. F.; Borges, D. L. G.; Welz, B.; Heitmann, U.; Curtius, A. J.; Spectrochim. Acta, part B 2005, 60, 693 .

6. Rao, K. S.; Balaji, T.; Rao, T. P.; Babu, Y.; Naidu, G. R. K.; Spectrochim. Acta, part B 2002, 57, 1333.

7. Barany, E.; Bergdahl, I. A.; Bratteby, L. E.; Lundh, T.; Samuelson, G.; Schütz, A.; Skerfving, S.; Oskarsson, A.; Sci. Total Environ. 2002, 286, 129.

8. El-Defrawy, M. M. M.; Posta, J.; Beck, M. T.; Anal. Chim. Acta 1980, 115,155 .

9. Eskandari, H.; Ghaziaskar, H. S.; Ensafi, A. A.; Anal. Sci. 2001, $17,327$.

10. Gupta, A.; Khopkar, S. M.; Talanta 1995, 42, 1493.

11. Cadore, S.; Goi, R. D.; Baccan, N.; J. Braz. Chem. Soc. 2005 , 16, 957.

12. Manzoori, J. L.; Sorouradin, M. H.; Haji Shabani, A. M.; Microchem. J. 1999, 63, 295.

13. Tong, A.; Akama, Y.; Tanaka, S.; Analyst 1990, 115, 947.

14. Cundeva, K., Stafilov, T.; Pavlovska, G.; Microchem. J. 2006, $65,165$.
15. Giné, M. F.; Patrez, A. F.; Silva, E. L.; Sarkis, J. E. S.; Kakazu, M. H.; J. Braz. Chem. Soc. 2008, 19, 471.

16. Afkhami, A.; Madrakian, T.; Siampour, H.; J. Braz. Chem. Soc. 2006, 17, 797.

17. Surme, Y.; Narin, I.; Soylak, M.; Yuruk, H.; Dogan, M.; Microchim. Acta 2007, 157, 193.

18. Lemos, V. A.; Santos, J. S.; Baliza, P. X.; J. Braz. Chem. Soc. 2006, 17, 30 .

19. Bezerra, M. A.; Arruda, M. A. Z.; Ferreira, S. L. C.; Appl. Spectrosc. Rev. 2005, 40, 269.

20. Paleologos, E. K.; Giokas, D. L.; Karayannis, M. I.; TrAC, Trends Anal. Chem. 2005, 24, 426.

21. Silva, M. F.; Cerutti, E. S.; Martinez, L. D.; Microchim. Acta 2006, 155, 349.

22. Alwood, D. A.; Coord. Chem. Rev. 1997, 195, 267.

23. Arena, F.; Floriana, C.; Chiesi-Villa, A.; Guastini, C.; Inorg. Chem. 1986, 25, 4589.

24. Alizadeh, N.; Ershad, S.; Naeimi, H.; Sharghi; H.; Shamsipur, M.; Fresenius J. Anal. Chem. 1999, 365, 511.

25. Zare, H. R.; Memarzadeh, F.; Gorji, A.; Ardakani, M. M.; J. Braz. Chem. Soc. 2005, 16, 571.

26. Khorrami, A. R.; Naeimi, H.; Fakhari, A. R.; Talanta 2004, 64, 13.

27. Dadfarnia, S.; Haji Shabani, A. M.; Tamaddon, F.; Rezaei, M.; Anal. Chim. Acta 2005, 539, 69.

28. Haji Shabani, A. M.; Dadfarnia, S.; Jafari, A. A.; Shahbasi, Z.; Can. J. Anal. Sci. Spectrosc. 2006, 51, 194.

29. Lee, C. C.; Syamal, A.; Theriot, L. J.; Inorg. Chem. 1971, 10, 1669.

30. Muto, Y.; Bull. Chem. Soc. Jpn. 1960, 33, 1242.

31. Laepsada, M. E. F.; Pavon, J. L. P.; Cardero, B. M.; Analyst 1993, 118, 209.

32. Frankewich, R. P.; Hinze, W. L.; Anal. Chem. 1994, 66, 944.

33. Giokas, D. L.; Paleologos, E. K., Tzouwara-Karayanni, S. M.; Karayannis, M. I.; J. Anal. At. Spectrom. 2001, 16, 521.

34. Chen, J.; Teo, K. C.; Anal. Chim. Acta 2001, 434, 325. 
35. Manzoori, J. L.; Karim-Nezhad, G.; Anal. Sci. 2003, 19, 579.

36. Nascentes, C. C.; Arruda, M. A. Z.; Talanta 2003, 61, 759.

37. Manzoori, J. L.; Bavili-Tabrizi, A.; Microchim. Acta 2003, 141, 201.
38. Lemos, V. A.; Franca, R. S.; Moreira, B. O.; Sep. Purif. Technol. 2007, 54, 349.

39. Ghaedi, M.; Shokrollahi, A.; Ahmadi, F.; Rajabi, H. R.; Soylak, M.; J. Hazard. Mater. 2008, 150, 533.

Received: September 15, 2008 Web Release Date: March 13, 2009 